\title{
Gender Inequality and Violence against Women
}

\author{
Ibtisam Kamal* \\ Faculty of Engineering, Soran University, Kurdistan Region Iraq \\ Received: 此 May 24, 2018; Published: 盋 May 31, 2018 \\ *Corresponding author: Ibtisam Kamal, Faculty of Engineering, Soran University, Kurdistan Region Iraq, Email: \\ Ibtisam.kamal@soran.edu.iq
}

\begin{abstract}
All over the world, women are facing different challenges, among them the increase in violance with increasing in life developments and the accelerating in social change. In spite of numerous numbers of studies imply the impact of socialization and tradition on women subordination, and the advocated ideas of democracy and secularism support women movement and needs as well, women across the world aspirations are still far from achieving the optimum situation. The curent paper reviews the role of gender inequality and the associated aspects, and highlighting the principles of the physical differences between women and men that may explain why men play as the principal factor in violence against women.
\end{abstract}

Keywords: Women; Violence; Gender; Inequality; Biology

\section{Introduction}

The subject of violence against women is a complex issue concerning women's lives and aspirations around the world. The increasing violence against women knows no social, economic or national boundaries. Physical and psychological abuse, female genital mutilation, fear from family revenge and dread from manifesting any sign of freedom, suicide by self-burning, polygamy, marrying older for younger, are practices and problems facing the societies in general, and in particular the middle east and other developing countries. These problems have never ended and even minimized or solved yet. It is estimated that one in three women may experience physical or sexual abuse during their lifetime [1].

Thousands cases of violence against women are reported every year. Most of the reported cases including murders or suicides, self-immolation incidents, discrimination complaints and cases of rape. Women's rights activists and monthly statistics reports by directories and centers for violence against women across the world have never hide the figures and announced that violence against women has increased over the last years [2]. Women are worry about the wave of murdering woman that has swept in the last few years. In some middle east countries and other developing countries, girls and women are still struggling in varying proportions to get freedom of choosing partners and lovers, they fall under the traditional, cultural, and religious pressures and, driven by ignorance and illiteracy In such societies, women suffer from subordination and gender tradition by which women are made subordinate.
Most of the studies carried out by women's empowerment groups, non-governmental organizations, institutes and universities, media and citizens of societies, imply different cases and estimations on the violence against women confirmed that social, economic, administration and politic reasons are beyond the violence against women [3-5]. However, the real number of violation is much higher than that accounted from official complains because most of women who are attacked refuse to announce. Never the less, encouraging women to come forward and telling authorities through legal means about violations has had a positive impact. It is well recognized that biology is often interwoven with socialization and tradition to get dissimilar ideals that make men dominant in society. The three factors all refer to the conservation of gender inequality $[6,7]$. The task of this short review is to focus on analysis the items of the source of the gender biology by which men made dominate, and highlighting the principles of the physical differences between women and men from biological point of view that may explain why men play as the principal factor in violence against women.

\section{The Gender Inequality Phenomenon}

\section{Gender development of Male and Female}

The scientific researches conclud that men and women excel in different areas $[8,9]$. Men are better than women at some skills, and vice versa. Gender development has been attributed to environmental factors as social learning theory suggests [10], and to biological factors [11]. However, most psychologists believe that combination of the two factors accounts for gender development. 
The biological factors are identified by sex differences in brain structure, evolution, genetics, hormones, or neurotransmitter, while sociocultural factors are those related to culture or upbringing. Evolutionary biology argues that there are some differences between males and females and those differences are programmed within the DNA from the moment of conception. Never the less, further research on the biological differences between male and female still has a long way to travel. The fundamental differences between the sexes that are rooted in biology are summarized in the following sessions.

\section{The Differences in the Genes}

Professor Steven Goldberg, Chairman of the Department of Sociology at City College of New York, has written a book with the provocative title, Why Men Rule-A Theory of Male Dominance. He declared that males and females are different in their genetic and hormonally-driven behavior. However he mentioned that the difference does not mean that one sex is superior or inferior to another, and gender has different strengths and weaknesses [12]. Science makes plain that males and females are different from the moment of conception. The differences between men and women are evident in the chromosomes which carry inherited traits from the father and mother. Humans have 23 pairs of chromosomes within each cell; twenty-two of these are alike in both males and females. But, when we come to the twenty-third pair, the sexes are not the same. Every woman has in her cells two of what we call the $\mathrm{X}$ chromosome. But a man has just one X---its mate being the much smaller Y. The presence of this influential Y chromosome, results in all the genetic differences that there are between a man and a woman [13]. So, motivated to the cellular level, males and females are different.

\section{The differences in Hormones}

The sex hormones primarily estrogen and testosterone found to have a significant impact on the behavior of males and females. Why do boys typically like to play with trucks and girls like to play with dolls? Feminists usually claim this is the result of socialization, but there is growing scientific evidence that boys and girls are greatly influenced by their respective hormones. Hormone is a "chemical messenger." It is a molecule released by a cell or a gland in one part of the body that travels to and controls the function of another cell or gland somewhere else in the body. The major female and male hormones can be classified as estrogens or androgens. Both classes of male and female hormones are present in both males and females alike, but in vastly different amounts. Most men produce 6-8 mg of the male hormone testosterone (an androgen) per day, compared to most women who produce $0.5 \mathrm{mg}$ daily. Female hormones, estrogens, are also present in both sexes, but in larger amounts for women. Table 1 shows male and female hormones, their production sources and functions. In brief, in female the main hormones are estrogen and progesterone, while in male it is mainly testosterone.
However, female hormones such as estrogen and progesterone can be taken by males for medical conditions such as testicular cancer, prostate enlargement and aromatase deficiency [14].

Table 1: Male and female hormones, their production source and main function (14).

\begin{tabular}{|c|c|c|c|}
\hline Hormone & Gender & $\begin{array}{c}\text { Source of } \\
\text { Production }\end{array}$ & Main Function \\
\hline Testosterone & Male & Testes & $\begin{array}{c}\text { Stimulate the male } \\
\text { secondary sexual } \\
\text { characteristics }\end{array}$ \\
\hline Estrogen & Female & Ovaries & $\begin{array}{c}\text { Stimulate the female } \\
\text { secondary sexual } \\
\text { characteristics; repair of the } \\
\text { wall of the uterus; controls } \\
\text { ovulation }\end{array}$ \\
\hline Progesterone & Female & $\begin{array}{c}\text { Ovaries and } \\
\text { Placenta }\end{array}$ & $\begin{array}{c}\text { Prevents the wall of uterus } \\
\text { breaking down }\end{array}$ \\
\hline
\end{tabular}

It was proved that female hormone treatment in men carries a number of risks, because it suppresses the production of testosterone. Increase in the risk of breast cancer was observed, as well as an increased risk of stroke, particularly among smokers, in addition, an increased chance of the development of liver and gall bladder disease may be seen; however a decreased risk in the development and growth of prostate enlargement and prostate cancer is possible and a decreased chance of heart attack is probable. Testosterone is primarily responsible for the development of muscle mass and bone tissue in men. With female hormone usage, large muscle groups such as the chest, legs and arms may begin to shrink and bones may become more porous and brittle, thereby contributing to weakness and bone fracture. In addition, fat storage in men who take hormones may be increased, leading to a feminization of body shape. On another hand, testosterone has been shown to play a factor in assertiveness and aggression, men who take female hormones may become less assertive. The studies conducted revealed that male hormones trigger aggression and female hormones trigger nurture [15].

\section{Brain Differences}

The differences in the anatomies and personalities of males and females are well-known to everyone, but only relatively recently have there been studies which show that there are substantial differences between the male and female brain, as well. These differences can be quite pronounced, and in many cases account for traits that generally apply more to women than men, and vice versa. The structures and systems of the male and female brain are basically similar, but the ways in which they work and integrate can be very interesting and even surprising. Women have the brain structure that supports a more conscious use of their intuitive faculties than men. The sex-specific differences in the brain are located both in the primitive regions, and in the neocortex--the higher brain regions $[16,17]$. The neocortex contains 70 percent of the neurons in the central nervous system, and it is divided into 
two hemispheres joined by a 200-million fiber network called the corpus callosum. The left hemisphere controls language analysis and expression and body movements while the right hemisphere is responsible for spatial relationships, facial expressions, emotional stimuli, and vocal intonations. Table 2 list female and male brain characteristics. The region different in dimensions in male and female brain are such as, in women, the corpus colosum (the part of the brain that connects the left and right sides) is twice as large in diameter as that of men. This makes it easier for women to access and integrate their intuitive faculties with their analytical faculties, something necessary for spiritual ascension and for a rebalancing of the female/male. This also allowing women to be more in touch with their feelings and those of others and results in a woman's increased ability to bond and take care of other people, as compared to men. Limbic system differences are probably responsible for the fact that women are seen as the primary caretakers of young children in every known culture.

Table 2: Female and male brain characteristics.

\begin{tabular}{|c|c|}
\hline $\begin{array}{c}\text { Female (Right Brain) } \\
\text { Characteristics }\end{array}$ & Male (Left Brain) Characteristics \\
\hline Circular & Hierarchical \\
\hline Being & Doing \\
\hline Surrender & Aggregation \\
\hline Wholistic thinking & Analytical/ sequential thinking \\
\hline Abstract conceptualization & Concrete conceptualization \\
\hline Patience & Impatience \\
\hline Tranquility & Striving \\
\hline Nurturing & Rushing \\
\hline Receiving (like a cupped hand) & Aggressive/thrusting (like a \\
\hline Spontaneous/synthesizing & Incremental \\
\hline Emotional & Logical \\
\hline Creative & Analytical \\
\hline Intuitive & Mathematical \\
\hline Calm & Busy \\
\hline Soft & Hard \\
\hline Allowing & Controlling \\
\hline
\end{tabular}

It should be noted that no scientific study has found a difference in general intelligence levels between the sexes. This is, of course, no small point, but the male and female brain do differ in character and comparative advantage. One difference that has been known for quite a while is that, on average, the male brain contains a higher number of cells than the average female brain, by about four percent, causing it to weigh about 3.5 ounces (100 g) more. The female brain, while containing slightly fewer brain cells, also contains a higher number of connections between the cells. These general differences may account for the different ways in which men and women process language, judge the speed of an object, and estimate the passage of time, among other things.
This suggests something that most of us know from experience, namely that men often excel in tasks that require concentration in local areas of the brain, such as mathematics. Women, on the other hand, are generally better at assimilating and integrating information for uses such as verbal expression. This is not just a common cultural observation, as it was found to be a scientifically valid conclusion in a study conducted by the University of California at Irvine in 2004 [18]. Differences in the ways men and women communicate is also a function of sex-specific areas of the brain $[19,20]$. Women seem to have an enhanced awareness of "emotionally relevant details, visual cues, verbal nuances, and hidden meanings," while male infants are more interested in objects than in people, female infants respond more readily to the human voice than do male infants Data, pulled from 10,000 American men and women who took a questionnaire that measured 15 variations of personality traits, record that men and women feel and behave in very specific (and gendered) ways. The analysis of results showed that men are more dominant, reserved, utilitarian, vigilant, ruleconscious, emotionally stable. While women are more deferential, warm, trusting, sensitive, emotionally reactive [21]. On another hand, It has been demonstrates that the exceptional density on the $\mathrm{X}$ chromosome of genes are essential for normal brain development, therefore, sex differences in $\mathrm{X}$ gene expression could influence the brain [22].

\section{Strength and Endurance}

Not only are men and women fundamentally different in the way their brains are wired, they are also vastly different in physical strength and endurance. The differences are rooted within both the genes and the hormones of males and females. A study noted that women only have 55- 58 percent of the upper body strength of men and on average, are only 80 percent as strong as a man of identical weight [23]. Sex differences also appear by the age of three in the ability of males and females to throw a ball far and accurately. Moreover, another aspect of that is important is that of the dependance of the pharmacological response on sex-gender. For example, women seemed to have a worse safety profile, with drug adverse reactions being more frequent and severe in women than in men [24]. On another hand, a reliable muscle strength and endurance evaluation of trunk flexor and extensor muscles was investigated in a study with minimum detectable changes ranged from $7 \%-20 \%$, with a tendency to be higher in females compared to males [25].

\section{Conclusion}

It is true that men are physically and rationally superior, but women are morally superior. Although females simply do not have the strength or endurance necessary to be effective in doing some functions, but women have both the brain power and skill sand in some instances superior abilities to compete with men. Feminist leaders naively believe that physical differences between males 
and females particularly in strength and endurance should not be taken into consideration to encourage men to violate woman or retard her role in society. Women believe that they are not created to be the same as men. Their natural attributes, affections, and personalities are entirely different from a man's. They consist of faithfulness, benevolence, kindness, and charity. While man has an aggressive and competitive nature. However, they believe that men and women are created as complements. They complete one another.

Women are waiting for serious investigation and planning to be processed in order to identify the causes of violence and instigate counter-measures to limit the phenomenon. Women are looking for government and judicial leaders to pay attention to the laws against domestic violence, and work together for real application of the laws on the ground within their different items. They highly believe that accurate application of the laws resulted in safety and stability in the society daily life. Women believe that time is arrived to move from a world based on duality of male/female to world based on unity, moving from life on service to self into a life to service to others, to living in peace and to end violence forever.

\section{References}

1. (2017) Violence against women: despite improvements, persistence, UNIOGBIS.

2. (2015) The World's Women: Trends and Statistics. United Nations Statistics Division 6: 139-160.

3. Chaudhry AG (2004) Violence Against Women-A Case Study. International Journal of Agriculture and Biology 6(4): 669-671.

4. Shalhoub-Kevorkian N (1999) Law, Politics, and Violence Against Women: A Case Study of Palestinians in Israel. Law and policy 21(2): 189-211.

5. Abed Al-Anni, LMA (2010) Types of violence against Iraqi women after USA occupatio. The eightth conference of Faculty of Education, Alyarmook University, Erbid, Jordan p. 20-24.

6. (2017) Violence against women hurts Arab economies, UN says. MEE and agencies.

7. Balos B, Louise M (1994) Law and Violence against Women: Cases and Materials on Systems of Oppression. Carolina Academic Press, North Carolina, USA.

8. Halpern DF, Benbow CP, Geary DC, Gur RC, Hyde JS, et al. (2007) The science of sex differences in science and mathematics. Psychological Science in the Public Interest 8(1): 1-51.

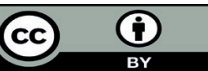

This work is licensed under Creative Commons Attribution 4.0 License

To Submit Your Article Click Here:

Submit Article

DOI: $10.32474 /$ OAJBEB.2018.02.000142
9. Gneezy U, Leonard KI, List JA (2009) Gender differences in competition: evidence From a matrilineal and a patriarchal society. Econometrica 77(5): 1637-1664.

10. Addis ME, Mansfield AK, Syzdek MR (2010) Is "Masculinity" a Problem?: Framing the Effects of Gendered Social Learning in Men. Psychology of Men \& Masculinity 11: 77-90.

11. Levant RF, Hall RJ, Williams CM, Hasan NT (2009) Gender Differences in Alexithymia. Psychol Men Masc 10: 190-203.

12. Goldberg S (1994) Why Men Rule: A Theory of Male Dominance. Open Court publishing company, USA.

13. Ngun TC, Ghahramani N, Sánchez FJ, Bocklandt S, Vilain E (2011) The Genetics of Sex Differences in Brain and Behavior. Front Neuroendocrinol 32(2): 227-246.

14. Hormones (Uses in Reproduction).

15. Butts C, Stemberg (2004) Different approaches to understanding autoimmune rheumatic diseases: the neuroimmunoendocrine system. Best Practice \& Research Clinical Rheumatology 18(2): 125-139.

16. Blum D (1998) Sex on the Brain: The Biological Differences Between Men and Women. Penguin.

17. Ders E, Steinmetz Hj, Ncke L (2002) Brain size and grey matter volume in the healthy human brain. NeuroReport 13(17): 2371-2374.

18. Arnold AP (2004) Sex chromosomes and brain gender. Nature Reviews Neuroscience 5 (9): 701-708.

19. Jordan-Young R (2010) Brain Storm: The Flaws in the Science of Sex Differences. Harvard University Press, USA.

20. Vallender EJ, Lahn BT (2004) How mammalian sex chromosomes acquired their peculiar gene content. BioEssays 26: 159-169.

21. Chateau Heartiste (2012) Study: Men And Women Are Different Species.

22. Zechner U, Wilda M, Kehrer-Sawatzki H, Vogel W, Fundele R, et al. (2001) A high density of X-linked genes for general cognitive ability: a run-away process shaping human evolution? Trends Genet 17: 697-701.

23. Michael E Levin (1987) Feminism and Freedom (1 ${ }^{\text {st }}$ edn.), Social Science, p. 120.

24. Franconi F, Campesi I (2014) Pharmacogenomics, pharmacokinetics and pharmacodynamics interaction with biological differences between men and women. Br J Pharmacol 171(3) : 580-594.

25. García-Vaquero MP, Barbado D, Juan-Recio C, López-Valenciano A, VeraGarcia FJ (2016) Isokinetic trunk flexion-extension protocol to assess trunk muscle strength and endurance: Reliability, learning effect, and sex differences. Journal of Sport and Health Science.

\section{OAJBEB}

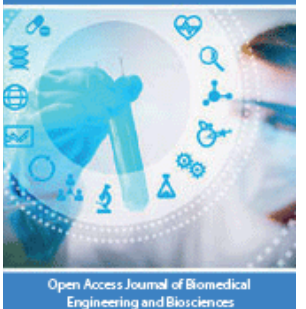

Open Aoress Joums of Biomedikal
Engineering and Biosciences
Open Access Journal of Biomedical Engineering and Biosciences

\section{Assets of Publishing with us}

- Global archiving of articles

- Immediate, unrestricted online access

- Rigorous Peer Review Process

- Authors Retain Copyrights

- Unique DOI for all articles 